\title{
The Effect of the Ethical Culture of the Audit Instituteon the Auditor's Impartiality
}

\author{
Dr. Zohreh Hajiha \\ Associate Professor of Accounting, Tehran East Branch, Islamic Azad University, Tehran, Iran \\ drzhajiha@gmail.com \\ Masoumeh Ebrahimi Balanga \\ Postgraduate Student, Tehran East Branch, Islamic Azad University, Tehran, Iran \\ ebrahimi_m1391@yahoo.com
}

\begin{abstract}
Impartiality is essential in achieving sensitive and precise judgments.The findings should be the basis for the auditor's judgment and no personal interests should play a part in the judgment of the auditor.The credibility of the audit necessitates the existence of an impartial attitude, and this approach adds to the ability to rely on the auditor's judgment.The main objective of the present study was to examine the effect of the ethical culture of the audit instituteon auditor's impartiality.The statistical population of the study included 420 auditors of the community of official accountants.The sample size was 201 people based on the Cochran formula.Accordingly, using a library and field method, the questionnaire was distributed among the statistical sample to test the research hypotheses.In order to test the hypothesis of the research, regression analysis was performed using SPSS software. To verify the validity of the construct, confirmatory factor analysis, and Lisrel software were used.The results indicated that the ethical culture of the audit institutes with the dimensions of ethical behavior of senior managers of the audit institute, ethical behavior with clients and ethical behavior of the staff of the audit institute had a significant effect on the impartiality of the auditor and all the research hypotheses were accepted.
\end{abstract}

Keywords: Ethical culture of audit institutes, Ethical behavior of senior managers of the audit institute, Ethical behavior with clients, Ethical behavior of the staff of the audit institute, Auditor's impartiality.

\section{Introduction}

Audits in today's advanced economic world are the critical sciences, so the reports provided by auditors should be significantly efficient, reliable, realistic and non-existent, so auditors should, in addition to professional competence, have a high degree of honesty, pride, professional reputation, independence, and impartiality.As a result, ethics in auditing are important for those who rely on accounting services (Hassan Yegane et al., 2011).Ethics, as one of the most important issues of importance for the trust of the international community, is concerned with the ability of the accounting and auditing profession.Unfortunately, the unethical and nonprofessional behaviors of large audit firms, including Enron and WorldCom, have caused global problems and distrust of individuals to accounting and auditing institutes.Due to the need of the community members for a trustworthy reference that, without any bias, can confirm the company's financial statements, the importance of paying attention to accounting ethics for professional accountants and those who rely on accounting services is very important. Moreover, the accounting profession should develop ethical principles and laws that require its members to reach a level of patience that goes beyond these legal and regulatory requirements, and these ethical principles are institutionalized in them (Kamyabi and Noushabadi, 2013).Due to the lack of studies regarding the role of the ethical culture of the audit institute on the auditor's impartiality, conducting this research was important and necessary.The main purpose of the present study was to examine the effect of the ethical culture of the audit institute on auditor's impartiality.In the following of this study, the second section has dealts with the literature of the subject and the background of the research.In the third section, the designing hypotheses have been presented.In the fourth, fifth and sixth sections, the research method, the society, and the statistical sample and research tools have been expressed, respectively.In the seventh and eighth sections, descriptive and inferential statistics have been presented, and in the ninth section, conclusions and suggestions have been discussed. 


\section{Literature review and background of the study}

Impartiality is necessary for achieving sensitive and precise judgments. The findings should be the basis for the auditor's judgment and no personal interests should play a part in the judgment of the auditor.The credibility of the audit is the existence of an impartial approach, and this approach adds to the ability to rely on the auditor's judgment.The freedom to act in the examination and reporting of the audit, selection, and evaluation of evidence is the basis for the professional judgment of the auditor.The auditor must have freedom of action and independence.The emphasis on independence is because the testing and reporting process is the responsibility of the auditor and not the information provider.In fact, the auditor should have an impartial role in the testing and reporting process and should not advocate the interests of the unit being investigated (Hesar Zadeh and Rajabizadeh, 2016).Some evidences have suggested that the auditor's long-term sustainability in a firm improves knowledge and quality of the audit.While other evidences have suggested that the auditor's long-term sustainability in a firm leads to limited judgment of the auditor (Svanberg \& Ohman, 2015).Regardless of which of these two views are taken into account, in the accounting literature, the issue of limiting impartiality of the auditor judgment is due to the existence of financial affinities and close relationships between customer and auditor that the auditor's turnover is viewed as an act of opposition (Jan \& Peter, 2016). What is certain is that the presentation of an impartial report is influenced by the auditor's behavior.Among many factors influencing the auditor's behavior, the ethical culture of the audit institutions is of utmost importantance.Previous studies in the audit branch have determined that the ethical decisions adopted by the auditors can be influenced by the ethical culture of their audit institutes. In addition, the leaders, through their actions, affect the ethical culture or the ethical atmosphere of the organization.This factor has a significant impact on organizational goals and behavior of the organization's members (Donaldson, 2005).Salehi (2016) studied the relationship between the professional ethics of auditor and audit quality. The results showed that the auditor's commitment to integrity and honesty, independence of the auditor and his professional impartiality, professional behavior in the audit profession, secrecy and professional performance of the auditor had a positive and significant effect on the quality of the audit.Maleki et al. (2015) investigated the factors that lead to non-professional and unethical behavior of accountants and auditors in a study entitled "Ethics in Accounting and Auditing". The results of the research showed that training students before entering the labor market, creating and maintaining an organizational and ethical culture in the institutes, aligning the country's education courses with international education courses can be effective in respecting ethical principles by the activists of this field.Mahdavi and Houshmand (2013) studied the effect of the ethical culture of the organization on the auditor's behavior in a study entitled "Investigation of the Impact of the Organization's Ethical Culture on Auditor's Behavior."The results of the research showed that the auditor's perception of the institute's ethical culture did not affect the auditors' behavior.Also, based on the findings, the auditor's perception of the institute's ethical culture and the personality characteristics of the auditors did not increase the quality of the audit through unusual auditors' behavior.Since improving the institute's ethical culture increases the quality of the audit, it can be deduced that improving the perception of auditors of the institute's ethical culture is an important step towards improving the audit profession and should be taken into consideration by the managers and partners of the audit firms.Zahmatkesh and Rezazadeh (2017) investigated the effect of work experience, professional competence, motivation, accountability, and impartiality of auditor on audit quality in a study entitled "Impact of Auditor's Attributes on Audit Quality".The results of the research indicated that the work experience, professional competence, motivation, accountability, and impartiality of auditor had a significant effect on audit quality.Jan and Peter (2016), in a study entitled "Impact of the Ethical Culture of the Audit Institute on Auditor Impartiality," used a field method to study the impact of the ethics culture of the audit institute on the auditor's impartiality.The results of the research indicated a significant impact of the ethical culture of the audit institute on auditor's impartiality.Olivia Furiady (2015) investigated the impact of auditor's experience, competence, motivation and accountability on audit quality by selecting a sample of 133 auditors in Jakarta, in a study entitled "Impact of Auditors' Experience, Competency, Motivation, and Accountability".T-test has been used to test the research hypotheses. The results of the research indicated that the auditor's experience, competence, motivation, and accountability had a significant effect on the quality of the audit.

\section{Research hypotheses}

According to Jan and Peter (2016), research hypotheses have been designed as follows:

The main hypothesis:

The ethical culture of the audit institute has a significant impact on the auditor's impartiality.

The secondary hypotheses:

The ethical behavior of senior managers of the audit institute has a significant impact on the auditor's impartiality.

Ethical behavior with clients has a significant impact on the auditor's impartiality.

The ethical behavior of the audit institute's staff has a significant impact on the auditor's impartiality. 


\section{Research Methodology}

The purpose of the present research was practical.According to the distribution of questionnaires for data collection, this research was a survey.In other words, in order to collect the required data and information, a library method was used. Accordingly, theoretical foundations and research literature were collected from Latin and Persian specialized books and magazines.Then, the data necessary for testing the research hypotheses have been extracted through the distribution of the questionnaire.In order to test the research hypotheses, regression analysis was performed using SPSS software. To evaluate the validity of the construct, confirmatory factor analysis, and Lisrel software were used.

\section{Statistical society and sample}

The statistical population of the study consisted of auditors of the Association of Certified Public Accountants such as Iran Mashhood (80 auditors), Matin Mohaseb (50 auditors), Hooshyar Momayez (70 auditors), Aban Hesab (20 auditors) and Mofidrahbar (200 auditors).Therefore, the statistical society included 420 auditors of the Association of Certified Public Accountants.Based on the Cochran formula from a limited population, the sample size was 201.The sampling method used in this research was stratified sampling.

\section{Research tool and validity and reliability of the research questionnaire}

In this research, a Likert scale was used to measure the variables. The questionnaire of this research consists of two main parts:

A. Respondent's profile: This part of the questionnaire is related to the demographic characteristics of respondents (including gender, academic status, age, and work experience).

B. Questions related to the variables of the research:

The ethics culture of the audit has the following dimensions:

Ethical behavior of senior managers: to measure this variable, Jan and Peter's standard questionnaire (2016) has been used. Six questions have been assigned to this variable.Ethical behavior of staff: to measure this variable, Jan and Peter's standard questionnaire (2016) has been used, with 7 questions assigned to this variable.Ethical behavior with customers: to measure this variable, Jan and Peter's standard questionnaire (2016) has been used. Four questions have been assigned to this variable.To measure the impartiality of the auditor in this research, Jan and Peter's standard questionnaire (2016) was used.In this study, Cronbach's alpha method was used to measure reliability.By analyzing the data using SPSS software, Cronbach's alpha coefficient was 0.918 . The validity of the questionnaire used in this study included content validity and construct validity.Content validity was confirmed by experts and professors.Construct validity was accomplished through confirmatory factor analysis and Lisrel software.In Table 1, the concepts and factors of the research have been shown along with their equivalents, which were used when comparing the paths of confirmatory factor analysis for facilitating the procedures of the study.

Table 1: Concepts and factors of the research along with their equivalents in the model

\begin{tabular}{|c|c|}
\hline Equivalent & Variable \\
\hline X1 & Ethical Behavior of Senior Managers \\
\hline X2 & Ethical behavior with customers \\
\hline X3 & Ethical behavior of staff \\
\hline Y & Auditor's impartiality \\
\hline
\end{tabular}

Figs. 1 and 2 showed the results of the confirmatory factor analysis of components and indices related to the variables of the research using the Lisrel software.Model factor loads in the standard estimation mode showed the effect of each of the variables or items in explaining and designing the variance of the variables or main factorsscores.In other words, factor load represented the correlation between each observer variable (question questionnaire) and the variable (factors).According to Fig. 1, the factor loads of each research question could be observed.For example, the factor load of the first question in the variable of ethical behavior of senior managers was 0.90 .In other words, this question explained approximately $0.10 \%$ of the variance of senior managers' ethical behavior. The value of 0.65 was also the error value (the amount of variance that cannot be explained by the first question, it is clear that the error value was lower and there were the higher coefficients and the greater correlation between the question and the relevant factor). The value of the numerical coefficient was between 0 and 1 , whichever approaching 1 , the value of the explanation of the variance increased. 


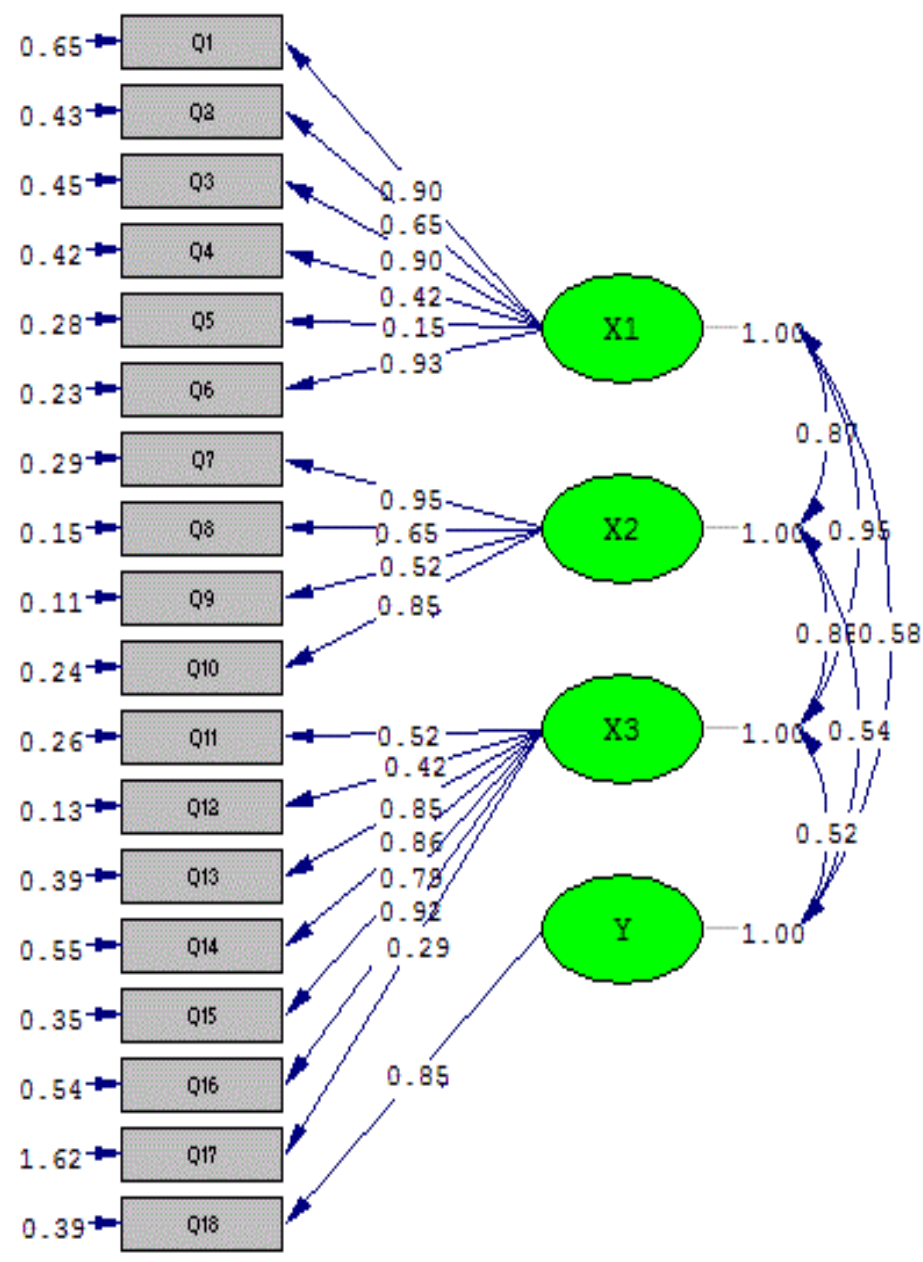

Chi-Square $=430.86, \mathrm{df}=146, \mathrm{P}-\mathrm{value}=0.00000, \mathrm{RMSEA}=0.021$

Figure 1: Correlation model between research variables and their indices in standard mode 


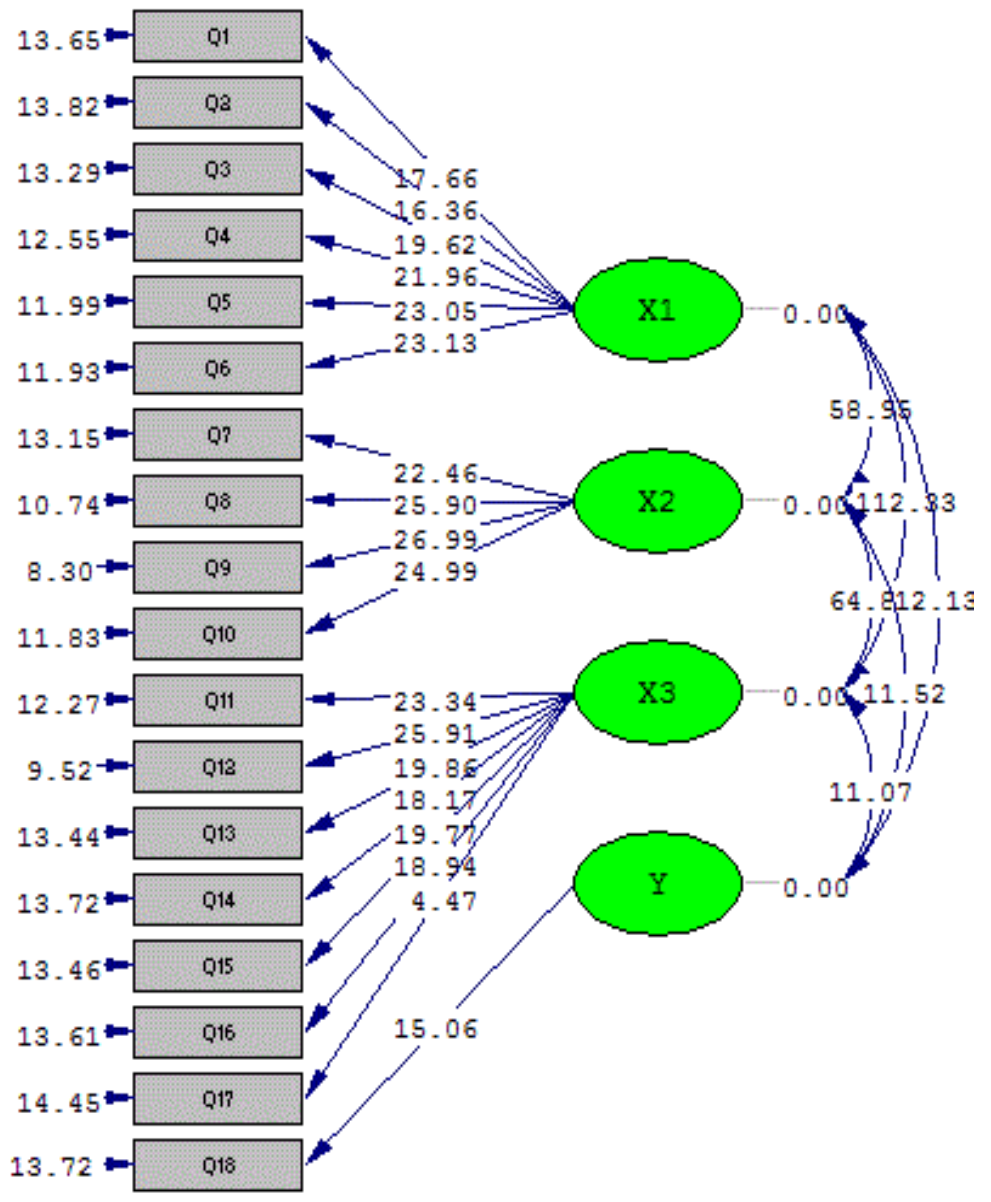

Chi-Square=430.86, $d f=146, \mathrm{P}-\mathrm{value}=0.00000, \mathrm{RMSEA}=0.021$

Figure 2: Correlation model between research variables and their indices in a meaningful mode

The next output of Figure 2 (model in the meaningful mode) showed the significance of the coefficients and parameters obtained by measuring the variables of the research model that all the obtained coefficients were significant.Values of significance test greater than 1.96 or smaller than 1.96 represented meaningful relationships. The results of the factor analysis presented in Figs 1 and 2 showed that all indicators of the research variables had acceptable t-value (greater than 1.96) and factor load.Also, the fitness indicators of the model indicated that the model was in a good position in term of fit index, since the ratio of $\chi 2$ to the degree of freedom $(\chi 2 / \mathrm{df})$ was equal to 2.95 , which was less than the permitted value of 3 . In addition, the root mean square error of approximation (RMSEA) was equal to 0.021, which was less than the permitted value of 0.1.Pvalue was less than 0.05 and was considered as suitable indicators for measuring the variables of the research.

\section{A normal test of data distribution}

To determine the appropriate statistical methods for analyzing the data and testing the research hypotheses, in the first stage, the distribution of factors and research variables in the sample should be determined.For this purpose, the Kolmogorov-Smirnov test has been used.The results of this test have been presented in Table 2.As the test results show, all factors in the sample were followed by a normal distribution (for the normal distribution of data, the significance level should be greater than 0.05). Therefore, to measure the research hypotheses, parametric tests were used. Regression analysis has been used in this research. 
Table 2: Results of the Kolmogorov-Smirnov test

\begin{tabular}{|c|c|c|c|c|}
\hline $\begin{array}{c}\text { Significance } \\
\text { level }\end{array}$ & $\begin{array}{c}\text { Kolmogorov-Smirnov } \\
\text { statistics }\end{array}$ & Mean & $\begin{array}{c}\text { Standard } \\
\text { deviation }\end{array}$ & Variable \\
\hline 0.143 & 0.148 & 3.37 & 1.048 & Senior Managers \\
\hline 0.272 & 0.998 & 3.16 & 1.006 & $\begin{array}{c}\text { Ethical behavior with } \\
\text { customers }\end{array}$ \\
\hline 0.747 & 0.678 & 3.15 & 0.720 & Staff \\
\hline 0.443 & 0.865 & 1.66 & 1.056 & Auditor's impartiality \\
\hline
\end{tabular}

\section{Testing research hypotheses}

Testing the first sub-hypothesis:

The ethical behavior of senior managers of the audit institute has a significant impact on the auditor's impartiality.

To test the first sub-hypothesis of the research, regression has been used and the results of this test have been presented in Tables 3, 4 and 5:

Table 3: Summary of the regression model for the impact of ethical behavior of senior managers of the audit institute on the auditor's impartiality

\begin{tabular}{|c|c|c|c|c|}
\hline Standard error & $\begin{array}{c}\text { Adjusted Coefficient } \\
\text { (R2 adj) }\end{array}$ & $\begin{array}{c}\text { Determination } \\
\text { Coefficient (R2) }\end{array}$ & $\begin{array}{c}\text { Correlation } \\
\text { Coefficient (R) }\end{array}$ & Model \\
\hline 1.145 & 0.096 & 0.100 & 0.316 & 1 \\
\hline
\end{tabular}

Table 3 shows the summary of the regression model for the impact of the ethical behavior of senior managers of the audit institute on the auditor's impartiality. The value of $\mathrm{R}$ indicated that there was a correlation of 0.316 between the ethical behavior of the senior managers of the audit institute and the auditor's impartiality.

Table 4: Analysis of variance

\begin{tabular}{|c|c|c|c|c|c|}
$\begin{array}{c}\text { Significance } \\
\text { level }\end{array}$ & F-statistics & $\begin{array}{c}\text { Average of } \\
\text { squares }\end{array}$ & $\begin{array}{c}\text { Degrees of } \\
\text { freedom }\end{array}$ & Sum of squares & Model \\
\hline & & 29.047 & 1 & 29.047 & Regression \\
\hline 0.000 & 22.147 & 1.312 & 199 & 260.993 & Other \\
& & & 200 & 290.040 & Total \\
\hline
\end{tabular}

Table 4 shows the analysis of variance among variables. Considering the significance of the $\mathrm{F}$ value at the $95 \%$ confidence level, it can be concluded that the presented regression model for testing the research hypothesis was a good model and the ethical behavior of the senior managers of the audit institute variable were capable of explaining the auditor's impartiality.

Table 5: Examining the impact of ethical behavior of senior managers of the audit institute on the auditor's impartiality

\begin{tabular}{|c|c|c|c|c|c|}
\hline \multirow{2}{*}{ Sig } & \multirow{2}{*}{$\mathrm{t}$} & \multirow{2}{*}{$\begin{array}{c}\text { Standard } \\
\text { coefficients }\end{array}$} & \multicolumn{2}{|c|}{ Non-standard coefficients } & \multirow{2}{*}{ Model } \\
\hline & & & Std.error & B & \\
\hline 0.000 & 14.758 & & 0.273 & 4.028 & Fixed \\
\hline 0.000 & -4.706 & -0.316 & 0.077 & -0.363 & Senior managers \\
\hline
\end{tabular}

As shown in Table 5, the significant level of the ethical behavior variable of the senior managers of the audit was less than 0.05 . Therefore, at $95 \%$ confidence level, the effect of this variable on the impartiality of the auditor was significant.

Testing the second sub-hypothesis:

Ethical behavior with customers has a significant effect on auditor's impartiality.

To test the second sub-hypothesis of the research, regression has been used and the results of this test have been presented in Tables 6, 7 and 8: 
Table 6: Summary of the regression model for the impact of ethical behavior with customers on the auditor's impartiality

\begin{tabular}{|c|c|c|c|c|}
\hline Standard error & $\begin{array}{c}\text { Adjusted Coefficient } \\
(\mathrm{R} 2 \mathrm{adj})\end{array}$ & $\begin{array}{c}\text { Determination } \\
\text { Coefficient (R2) }\end{array}$ & $\begin{array}{c}\text { Correlation } \\
\text { Coefficient (R) }\end{array}$ & Model \\
\hline 1.136 & 0.110 & 0.115 & 0.339 & 1 \\
\hline
\end{tabular}

Table 6 shows the summary of the regression model for the impact of the ethical behavior with customers on the auditor's impartiality. The value of $\mathrm{R}$ indicated that there was a correlation of 0.339 between the ethical behavior with customers and the auditor's impartiality.

Table 7: Analysis of variance

\begin{tabular}{|c|c|c|c|cc|}
\hline $\begin{array}{c}\text { Significance } \\
\text { level }\end{array}$ & F-statistics & $\begin{array}{c}\text { Average of } \\
\text { squares }\end{array}$ & $\begin{array}{c}\text { Degrees of } \\
\text { freedom }\end{array}$ & Sum of squares & Model \\
\hline \multirow{2}{*}{0.000} & 25.781 & 33.266 & 1 & 33.266 & Regression \\
& & 1.290 & 199 & 256.774 & Other \\
\hline
\end{tabular}

Table 7 shows the analysis of variance among variables. Considering the significance of the $\mathrm{F}$ value at the $95 \%$ confidence level, it can be concluded that the presented regression model for testing the research hypothesis was a good model and the ethical behavior with customersvariable were capable of explaining the auditor's impartiality.

Table 8: Examining the impact of ethical behavior with customers on the auditor's impartiality

\begin{tabular}{|c|c|c|c|c|c|}
\multirow{2}{*}{ Sig } & \multirow{2}{*}{} & \multicolumn{2}{|c|}{$\begin{array}{c}\text { Standard } \\
\text { coefficients }\end{array}$} & \multicolumn{2}{|c|}{$\begin{array}{c}\text { Non-standard } \\
\text { coefficients }\end{array}$} \\
\cline { 3 - 6 } & Beta & Std.error & $\mathrm{B}$ & Model \\
\hline 0.000 & 15.431 & & 0.264 & 4.081 & Fixed \\
\hline 0.000 & -5.077 & -0.339 & 0.080 & -0.405 & $\begin{array}{c}\text { Ethical behavior with } \\
\text { customers }\end{array}$ \\
\hline
\end{tabular}

As shown in Table 8, the significant level of the ethical behavior with customers was less than 0.05 . Therefore, at $95 \%$ confidence level; the effect of this variable on the impartiality of the auditor was significant.

Testing the third sub-hypothesis:

The ethical behavior of the staff of the audit institute has a significant impact on the auditor's impartiality.

To test the third sub-hypothesis of the research, regression has been used and the results of this test have been presented in Tables 9, 10 and 11:

Table 9: Summary of the regression model for the impact of ethical behavior of the staff of the audit institute on the auditor's impartiality

\begin{tabular}{|c|c|c|c|c|}
\hline Standard error & $\begin{array}{c}\text { Adjusted Coefficient } \\
(\mathrm{R} 2 \mathrm{adj})\end{array}$ & $\begin{array}{c}\text { Determination } \\
\text { Coefficient (R2) }\end{array}$ & $\begin{array}{c}\text { Correlation } \\
\text { Coefficient (R) }\end{array}$ & Model \\
\hline 1.177 & 0.045 & 0.050 & 0.224 & 1 \\
\hline
\end{tabular}

Table 9 shows a summary of the regression model for the impact of the ethical behavior of the staff of the audit institute on auditor's impartiality. The value of $\mathrm{R}$ indicated that there was a correlation of 0.224 between the ethical behavior of the staff of the audit institute and the auditor's impartiality.

Table 10: Analysis of variance

\begin{tabular}{|c|c|c|c|c|c|}
\hline $\begin{array}{c}\text { Significance } \\
\text { level }\end{array}$ & F-statistics & $\begin{array}{c}\text { Average of } \\
\text { squares }\end{array}$ & $\begin{array}{c}\text { Degrees of } \\
\text { freedom }\end{array}$ & Sum of squares & Model \\
\hline \multirow{2}{*}{0.001} & 10.500 & 14.537 & 1 & 14.537 & Regression \\
& & 1.384 & 199 & 275.503 & Other \\
\hline
\end{tabular}

Table 10 shows the analysis of variance among variables. Considering the significance of the $\mathrm{F}$ value at the $95 \%$ confidence level, it can be concluded that the presented regression model for testing the research hypothesis was a good model and the ethical behavior of the staff of the audit institute variable were capable of explaining the auditor's impartiality. 
Table 11: Examining the impact of ethical behavior of the staff of the audit institute on the auditor's impartiality

\begin{tabular}{|c|c|c|c|c|c|}
\multirow{2}{*}{ Sig } & \multirow{2}{*}{$\begin{array}{c}\text { Standard } \\
\text { coefficients } \\
\text { Beta }\end{array}$} & \multicolumn{2}{|c|}{ Non-standard coefficients } & Model \\
\cline { 4 - 6 } & & Std.error & $\mathrm{B}$ & Fixed \\
\hline 0.000 & 10.646 & & 0.374 & 3.983 & Ethical behavior of \\
staff
\end{tabular}

As shown in Table 11, the significant level of the ethical behavior of the staff of the audit institute was less than 0.05 . Therefore, at $95 \%$ confidence level, the effect of this variable on the impartiality of the auditor was significant.

Testing the main hypothesis:

The ethical culture of the audit institute has a significant impact on the auditor's impartiality.

To test the main hypothesis of the study, regression has been used and the results of this test have been presented in Tables 12, 13 and 14:

Table 12: Summary of the regression model for the impact of the ethical culture of the audit institute on auditor's impartiality

\begin{tabular}{|c|c|c|c|c|}
\hline Standard error & $\begin{array}{c}\text { Adjusted } \\
\text { Coefficient (R2 adj) }\end{array}$ & $\begin{array}{c}\text { Determination } \\
\text { Coefficient (R2) }\end{array}$ & $\begin{array}{c}\text { Correlation } \\
\text { Coefficient (R) }\end{array}$ & Model \\
\hline 1.141 & 0.102 & 0.106 & 0.326 & 1 \\
\hline
\end{tabular}

Table 12 shows a summary of the regression model for the impact of the ethical culture of the audit institute on auditor's impartiality. The value of $\mathrm{R}$ indicated that there was a correlation of 0.326 between the ethical culture of the audit institute and the auditor's impartiality.

Table 13: Analysis of variance

\begin{tabular}{|c|c|c|c|c|c|}
\hline $\begin{array}{c}\text { Significance } \\
\text { level }\end{array}$ & F-statistics & $\begin{array}{c}\text { Average of } \\
\text { squares }\end{array}$ & $\begin{array}{c}\text { Degrees of } \\
\text { freedom }\end{array}$ & Sum of squares & Model \\
\hline \multirow{2}{*}{0.000} & 23.615 & 30.768 & 1 & 30.768 & Regression \\
& & 1.303 & 199 & 259.272 & Other \\
\end{tabular}

Table 13 shows the analysis of variance among variables. Considering the significance of the $\mathrm{F}$ value at the $95 \%$ confidence level, it can be concluded that the presented regression model for testing the research hypothesis was a good model and the ethical culture of the audit institute variable were capable of explaining the auditor's impartiality.

Table 14: Examining the impact of the ethical culture of the audit institute on auditor's impartiality

\begin{tabular}{|c|c|c|c|c|c|}
\multirow{2}{*}{ Sig } & $\mathrm{t}$ & $\begin{array}{c}\text { Standard } \\
\text { coefficients } \\
\text { Beta }\end{array}$ & \multicolumn{2}{|c|}{ Non-standard coefficients } & Model \\
\cline { 4 - 6 } & 13.143 & Std.error & $\mathrm{B}$ & Fixed \\
\hline 0.000 & -4.860 & -0.326 & 0.100 & -0.484 & $\begin{array}{c}\text { Ethical culture of the } \\
\text { audit institute }\end{array}$ \\
\hline
\end{tabular}

As shown in Table 14, the significant level of the ethical culture of the audit institute was less than 0.05 . Therefore, at $95 \%$ confidence level; the effect of this variable on the impartiality of the auditor was significant.

\section{Discussion and conclusion}

The impartially report is influenced by the auditor's behavior and the ethical culture of the audit institutes with the dimensions of ethical behavior of senior managers of the audit institute, ethical behavior with customer, and ethical behavior of the staff of the audit institute, which is influenced by auditor's behavior and affects the auditor's impartiality.Previous studies in the audit branch have determined that the ethical decisions adopted by the auditors can be influenced by the ethical culture of their audit institutes; the leaders, through their actions, affect the ethical culture or the ethical atmosphere of the organization. This factor had a significant impact on organizational goals and behavior of the organization's members (Donaldson, 2005).In this research, the 
influence of the ethical culture of the audit institute on auditor's impartiality was studied.In order to achieve this goal, three minor hypotheses and one main hypothesis have been designed and tested, subsequently, their interpretation was discussed.The significance level for the ethical behavior variable of the senior managers was less than 0.05 , so at the $95 \%$ confidence level, the effect of this variable on the auditor's impartiality was meaningful.The coefficient of -0.316 reflected the negative impact of the senior managers' ethical behavior on auditor's impartiality.Accordingly, if the ethical behavior of senior managers of an audit increased one unit, the auditor's impartiality would be decreased to 0.316 units.Therefore, the first secondary hypothesis was accepted.The significance level of the ethical behavior variable with customers was less than 0.05 , so at the $95 \%$ confidence level, the effect of these variables on the auditor's impartiality was significant.The coefficient -0.339 represented the negative impact of ethical behavior with customers on the auditor's impartiality. Accordingly, if the ethical behavior with customers increased one unit, the auditor's impartiality would be decreased to 0.339 units.Therefore, the second secondary hypothesis was accepted. The significance level of the ethical behavior of staff was less than 0.05 , so at the $95 \%$ confidence level, the effect of these variables on the auditor's impartiality was significant.The coefficient -0.224 represented the negative impact of ethical behavior of staff on the auditor's impartiality. Accordingly, if the ethical behavior of staff increased one unit, the auditor's impartiality would be decreased to 0.224 units. Therefore, the third secondary hypothesis was accepted. The significance level of ethical culture variable of the audit institute was less than 0.05 , so at the $95 \%$ confidence level, the effect of these variables on the auditor's impartiality was significant.The coefficient -0.326 represented the negative impact of the ethical culture of the audit institute on the auditor's impartiality. Accordingly, if the ethical culture of the audit institute increased one unit, the auditor's impartiality would be decreased to 0.326 units.Therefore, the main hypothesis was accepted. What follows from the research is that the auditor should be impartial and not allow bias or prejudice to affect his impartiality. The auditor must always maintain his impartiality andavoid something that may be incompatible with his honesty and impartiality.What is certain is that the impartiality of the auditor is affected by ethics. The results of this study were somehow consistent with the results of Mahdavi and Houshmand (2013) and Sepasi and Najafi (2016) in Iran.Abroad, Jan and Peter (2016) have also conducted similar research that their research results showed the significant impact of the ethical culture of the audit institute on the auditor's impartiality, which was consistent with the results of this study.After completing the steps of scientific research, if the research was conducted in a systematic and research process, the researcher could make comments on the findings and research results as well as strategies and suggestions to improve future research.For this reason, suggestions have been presented in accordance with the results of the research.

Based on the first hypothesis:

It is suggested that senior managers consider ethical considerations in their decisions, take care of their ethical issues, and blame such cases when unethical behaviors, but it should be noted that observance of ethical issues does not undermine the auditor's impartiality because, according to the research results, this is possible.

Based on the second hypothesis:

Auditors and audit institutes meet ethical issues when dealing with customers, but to note that this issue should not undermine their impartiality.

Based on the third hypothesis:

Audit institutes are advised to define the requirements of the ethics of professional audit for staff and the continuous demand for professional ethics from staff, and the fact that these considerations may undermine the auditor's impartiality.

Based on the main hypothesis:

At the first stage, the attention of the audit institutes to the criteria of the ethical culture of the institute were identified in this study, and in the next stage, these cases were observed, while at the same time paying attention to the fact of ethical culture may undermine the auditor's impartiality.

According to researchers, there are still a number of different issues that may be important for future research. Some of these topics are as follows:

Investigation of the impact of religious belief on the auditor's impartiality

Investigation of the views of audit managers and audit institutes partners on the ethics culture of the audit institute on the auditor's impartiality.

Further research can explore ways to create and apply organizational ethical culture in audit institutes to improve the auditor's impartiality. 


\section{References}

[1] Hasas Yeganeh, Yahya, Babakhani, Jafar and Mehrnasab, Milad (2011), "The Effect of Audit Quality and Auditor's Properties on Profit Management", Master's Thesis, Allameh Tabatabaei University.

[2] Hesarzadeh, Reza and Rajabizadeh, Javad (2016), "The Investigation of the Interface Between the Two Dimensions of Skepticism and the Impartiality of Professional Hearing with the Professional Judgment of the Auditor and Its Effect on the Satisfaction level from Audit Fees", Master's Thesis, Ferdowsi University of Mashhad.

[3] Sepasi, Sahar and Najafi, Faezeh (2016), "The Effect of Auditors' Ethics on the Discovery of Manipulating of Financial Information ", Journal of Ethical Research, Vol. 6, No. 4.

[4] Salehi, Tabandeh (2016), "The Relationship between the Professional Ethics of the Auditor and the Quality of Auditing", Journal of Ethics in Science and Technology, Vol. 11, No. 3.

[5] Kamyabi, Yahya, Noushabadi, Seyyedeh Zahra (2013), "Professional Ethics in Accounting and Auditing", 1st National Conference on Accounting and Management.

[6] Maliki, Fatemeh, Saeedi, Parviz and Ghanbari, Jaber (2015), "The Ethics in Accounting and Auditing", The First International Management Conference, Economics, Accounting, and Educational Sciences, Sari, Future Research and Advisory Co., Payam Noor University of Neka.

[7] Mahdavi, Gholam Hossein, and Houshmand, Abdolhamid (2013), "Investigating the Impact of Ethical Culture of the Organization on Auditor's Behavior", Audit Knowledge of the 13th, No. 51, p. 1.

[8] Donaldson, W. (2005). "Speech by SEC Chairman: Remarks before the Financial Services Roundtable. U.S. Securities and ExchangeCommission.”'Retrieved from http://www.sec.gov/news/speech/spch 040105whd.htm.[04/10/2011]

[9] Jan Svanberg \& Peter Öhman(2016)," Does Ethical Culture in Audit Firms SupportAuditor Objectivity?”, Accounting in Europe, , 13:1, 65-79.

[10] Olivia Furiady,Ratnawati Kurnia,(2015)," The Effect of Work Experiences, Competency, Motivation, Accountability and Objectivity towards Audit Quality", 2nd Global Conference on Business and Social Sciences, Volume 211, Pages 328-335.

[11] Svanberg ,Jan and Öhman, Peter (2015)," Auditors' identification with their clients: Effects on audit quality",The British Accounting Review 47(4).

[12] Zhmatkesh,S, Rezazadeh,j(2017)," The effect of auditor features on audit quality", In Press, Corrected Proof,Volume 15, Issue 2. 